A. Sebastian López Chiriboga, MD

Jason L. Siegel, MD

William O. Tatum, DO

Jerry J. Shih, MD

Eoin P. Flanagan, MBBCh

Neurol Neuroimmunol Neuroinflamm

2017;4:e336; doi: 10.1212/

NXI.0000000000000336

Supplemental data at Neurology.org/nn

\section{STRIKING BASAL GANGLIA IMAGING ABNORMALITIES IN LGI1 AB FACIOBRACHIAL DYSTONIC SEIZURES OPEN}

Autoimmune encephalitis associated with antibodies targeting the neuronal surface antigen leucine-rich, glioma-inactivated 1 (LGI1) protein is accompanied by faciobrachial dystonic seizures (FBDS) in up to half of patients. These hallmark episodes can be mistaken for psychiatric disorders, particularly as the ictal episodes are usually not detectable with surface EEG electrodes. Accompanying imaging abnormalities help exclude psychiatric etiologies, localize the seizures, and improve our understanding of the pathogenesis. Herein, we present striking imaging abnormalities in a patient with FBDS from LGI1antibody encephalitis.

Case description. A 51-year-old man experienced a generalized tonic-clonic seizure in April 2015. He subsequently developed cognitive changes, visual hallucinations, and severe anxiety and was diagnosed with alcohol withdrawal syndrome at an outside institution; he did not receive immunotherapy. Approximately 12 weeks later, he developed progressive cognitive decline and abnormal movements characterized by posturinggrimacing of the hemiface and the ipsilateral arm, occurring up to 100 times per day (video at Neurology.org/nn). No abnormal discharges were identified during ictal episodes on surface EEG.

Neurologic examination revealed a Mini-Mental State Examination (MMSE) score of 24/30 (points were missed on orientation, calculation, and recall). He experienced multiple, frequent FBDS during the neurologic examination, but it was otherwise nonfocal.

Laboratory abnormalities included serum sodium of $129 \mathrm{mmol} / \mathrm{L}$ (normal 135-145 mmol/L) and positive LGI1 antibodies identified via cell-based assay. CSF analysis was normal, and LGI1 antibodies were not detected.

MRI of the brain showed T1 hyperintensities in the basal ganglia, right greater than the left, correlating with the prominent FBDS affecting the left arm more frequently. There were also restricted diffusion changes in the bilateral basal ganglia. 18F-fluorodeoxyglucose (18F-FDG) PET demonstrated foci of hypermetabolism in the bilateral basal ganglia and asymmetric hypermetabolism in the left temporal lobe (figure). Follow-up MRI, 16 months after the onset of symptoms, revealed prominent atrophy in the previously described restricted diffusion areas, particularly the caudate nuclei and mesial temporal lobes (figure). Extensive oncologic evaluation was negative.

The FBDS did not improve with antiseizure drugs, including the combination of levetiracetam and lacosamide. Significant improvement of his cognitive dysfunction (confirmed with formal posttreatment neuropsychometric testing and a bedside MMSE score of 29/30) and significant reduction in the frequency (1-2 per week) of FBDS were noted after administration of IV methylprednisolone $1 \mathrm{~g}$ for 5 days. He was transitioned to oral steroids and experienced a clinical relapse characterized by increased frequency of FBDS (up to 10 episodes daily) when prednisone was decreased from 20 to $10 \mathrm{mg}$ daily, requiring reinstitution of high-dose prednisone and initiation of mycophenolate mofetil and slow oral prednisone taper. The FBDS frequency decreased after 1 week and continued to improve over time; he has been seizure free for 7 months.

Discussion. This patient presented with classic features of LGI1-antibody encephalitis: subacute cognitive decline, hyponatremia, FBDS, and substantial improvement with immunotherapy. ${ }^{1}$ The striking imaging abnormalities illustrated in this report provide further evidence for the basal ganglia as the possible origin of FBDS and suggest evidence that ischemic injury occurs.

Although the pathophysiology of the radiographic finding remains unknown, the prominent restricted diffusion with apparent diffusion coefficient correlate and T1 and T2 hyperintensities, in this case, strongly suggest an ischemic injury from vascular, metabolic, or immune-mediated neuronal damage or due to the high metabolic demand from frequent epileptic activity. The changes observed in 18F-FDG PET/ $\mathrm{CT}^{2,3}$ characterized by hypermetabolic activity in the same areas corroborate this hypothesis. Because of vascular supply and high glucose and oxygen 

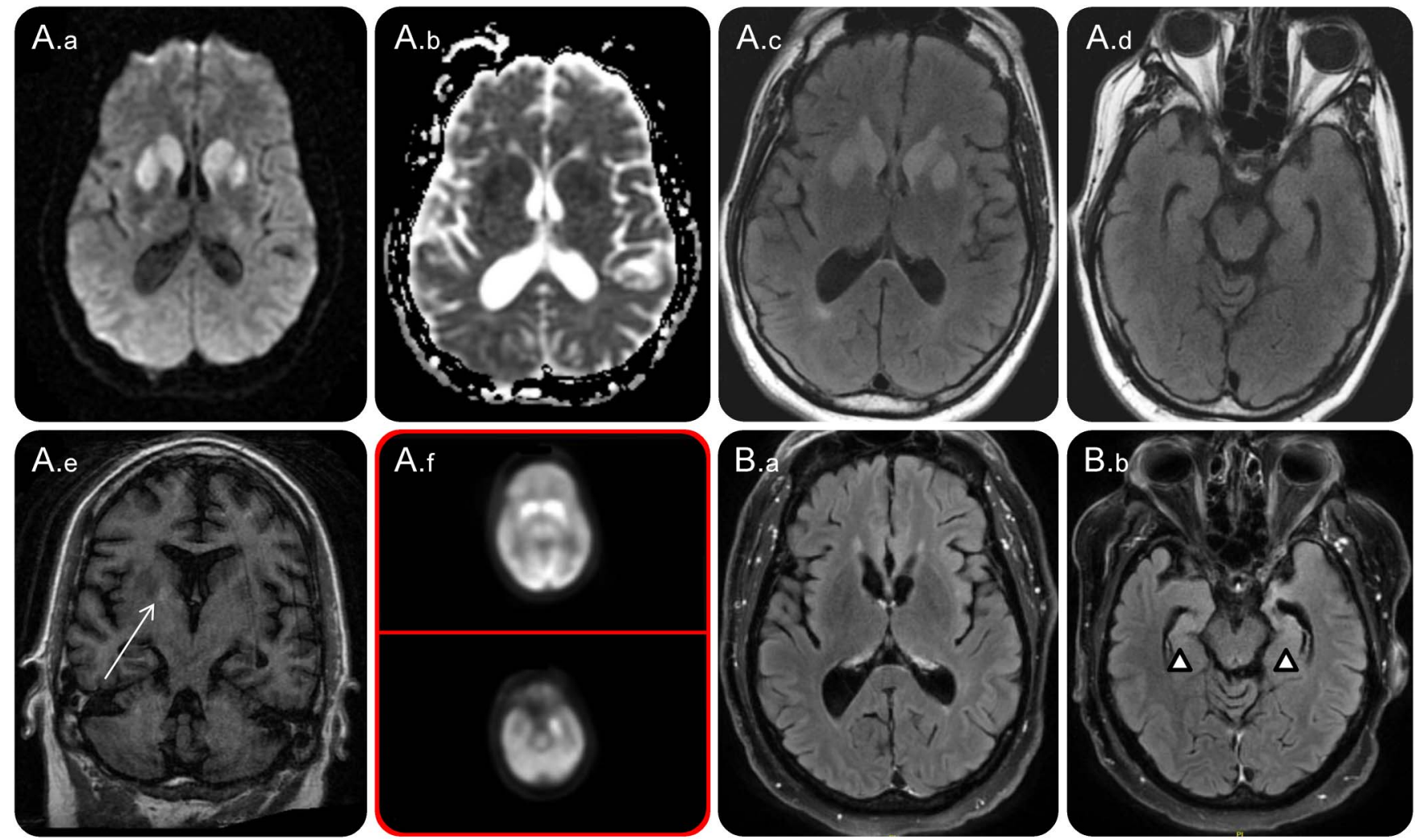

(A) Brain MRI obtained during relapse: (A.a) Prominent restricted diffusion and (A.b) apparent diffusion coefficient correlate with changes in the bilateral basal ganglia. (A.c) T2 fluid-attenuated inversion recovery (FLAIR) hyperintensities in the same "restricted diffusion" distribution. (A.d) FLAIR normal hippocampal size. (A.e) Coronal sequence showing T1 hyperintensities in the right basal ganglia. (A.f) 18F-fluorodeoxyglucose (18F-FDG) PET/CT. Intense 18F-FDG uptake is noted in the bilateral basal ganglia, asymmetric FDG uptake within the left medial temporal lobe. (B) Follow-up brain MRI: (B.a, B.b) 16 months after the onset of symptoms. Axial T2 FLAIR shows prominent caudate nuclei atrophy and bilateral hippocampal atrophy (arrowheads).

utilization, the deep gray nuclei are particularly vulnerable to ischemia or hypoglycemia. ${ }^{4}$

Our patient tested positive for LGI1 in the serum only, illustrating that, in this entity, some patients may have antibodies only detectable in the serum, ${ }^{5}$ whereas others may have antibodies only detectable in the CSF. ${ }^{6}$

This case adds LGI1-antibody encephalitis to the differential diagnosis of bilateral basal ganglia restricted diffusion along with hypoglycemia, hyperammonemia, carbon monoxide poisoning, exposure to cyanide and methanol, osmotic myelinolysis, and venous and arterial infarction. ${ }^{4}$ Given the restricted differential diagnosis of basal ganglia T1-hyperintensiy, this recently reported MRI accompaniment of a number of LGI1antibody associated FBDS is a particularly useful clue to this disorder. ${ }^{7}$

This case also illustrates the progression of MRI changes in LGI1 encephalitis and shows hippocampal and caudate atrophy as a consequence of neuronal loss.

Recognition of the radiologic characteristics of LGI1-antibody FBDS can help support the diagnosis, allow prompt serologic confirmation and early institution of immunotherapy, and thus prevent severe memory impairment resulting from delays in treatment. ${ }^{5,6,8}$

From the Department of Neurology (A.S.L.C., J.L.S., W.O.T.), Mayo Clinic, Jacksonville, FL; Department of Neurology (J.J.S.), University of California, San Diego; and Department of Neurology (E.P.F.), Mayo Clinic, Rochester, MN.

Author contributions: Dr. López contributed to the conception and design of the study; collection, analysis, and interpretation of the data; drafting and critical revision of the article; and generation/collection of the figures. Dr. Siegel contributed to the conception and design of the study; collection, analysis, and interpretation of the data; and generation of the figures. Dr. Tatum, Dr. Shih, and Dr. Flanagan contributed to the conception and design of the study; collection, analysis, and interpretation of the data; drafting and critical revision of the article; and generation/collection of the figures. All authors provided final approval of the article.

Study funding: There was no funding for this study.

Disclosure: A.S. López Chiriboga and J.L. Siegel report no disclosures. W.O. Tatum served on the SK Life Science Safety Board, is editor-inchieffor Epilepsy \& Behavior Case Reports, and receives publishing royalties from Demo and, Springer. J.J. Shih received research support from Eisai, UCB, and NSF. E.P. Flanagan reports no disclosures. Go to Neurology.org/nn for full disclosure forms. The Article Processing Charge was paid by the authors.

This is an open access article distributed under the terms of the Creative Commons Attribution-NonCommercial-NoDerivatives $L i$ cense 4.0 (CC BY-NC-ND), which permits downloading and sharing the work provided it is properly cited. The work cannot be 
changed in any way or used commercially without permission from the journal.

Received December 2, 2016. Accepted in final form January 9, 2017.

Correspondence to Dr. López Chiriboga: Lopez.alfonso@mayo.edu

1. Irani SR, Michell AW, Lang B, et al. Faciobrachial dystonic seizures precede Lgi1 antibody limbic encephalitis. Ann Neurol 2011;69:892-900.

2. Irani SR, Stagg CJ, Schott JM, et al. Faciobrachial dystonic seizures: the influence of immunotherapy on seizure control and prevention of cognitive impairment in a broadening phenotype. Brain 2013;136:3151-3162.

3. Kamaleshwaran KK, Iyer RS, Antony J, Radhakrishnan EK, Shinto A. 18F-FDG PET/CT findings in voltage-gated potassium channel limbic encephalitis. Clin Nucl Med 2013;38:392-394.
4. Finelli PF, DiMario FJ Jr. Diagnostic approach in patients with symmetric imaging lesions of the deep gray nuclei. Neurologist 2003;9:250-261.

5. van Sonderen A, Thijs RD, Coenders EC, et al. Anti-LGI1 encephalitis: clinical syndrome and long-term follow-up. Neurology 2016;87:1449-1456.

6. Arino H, Armangue T, Petit-Pedrol M, et al. Anti-LGI1associated cognitive impairment: presentation and longterm outcome. Neurology 2016;87:759-765.

7. Flanagan EP, Kotsenas AL, Britton JW, et al. Basal ganglia T1 hyperintensity in LGI1-autoantibody faciobrachial dystonic seizures. Neurol Neuroimmunol Neuroinflamm 2015;2:e161. doi: 10.1212/NXI.0000000000000161.

8. Finke $\mathrm{C}$, Prüss $\mathrm{H}$, Heine $\mathrm{J}$, et al. Evaluation of cognitive deficits and structural hippocampal damage in encephalitis with leucine-rich, glioma-inactivated 1 antibodies. JAMA Neurol 2017;74:50-59. 


\section{Neurology ${ }^{\oplus}$ \\ Neuroimmunology \& Neuroinflammation}

\section{Striking basal ganglia imaging abnormalities in LGI1 ab faciobrachial dystonic}

seizures

A. Sebastian López Chiriboga, Jason L. Siegel, William O. Tatum, et al.

Neurol Neuroimmunol Neuroinflamm 2017;4;

DOI 10.1212/NXI.0000000000000336

This information is current as of March 14, 2017

Neurol Neuroimmunol Neuroinflamm is an official journal of the American Academy of Neurology.

Published since April 2014, it is an open-access, online-only, continuous publication journal. Copyright

Copyright $\odot 2017$ The Author(s). Published by Wolters Kluwer Health, Inc. on behalf of the American

Academy of Neurology. All rights reserved. Online ISSN: 2332-7812.

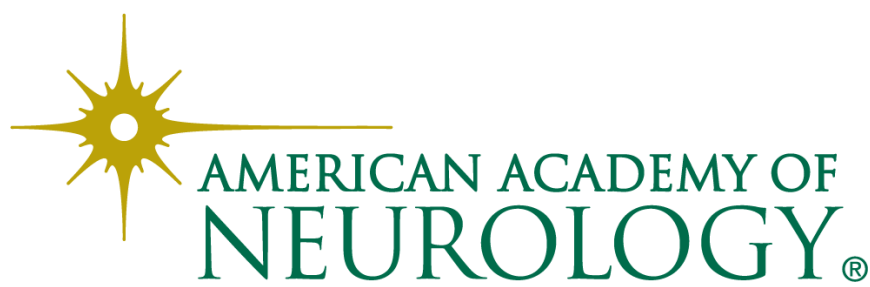




\section{Updated Information \& Services}

\section{Supplementary Material}

References

Subspecialty Collections

Permissions \& Licensing

Reprints including high resolution figures, can be found at: http://nn.neurology.org/content/4/3/e336.full.html

Supplementary material can be found at: http://nn.neurology.org/content/suppl/2017/03/14/4.3.e336.DC1

This article cites 8 articles, 0 of which you can access for free at: http://nn.neurology.org/content/4/3/e336.full.html\#\#ref-list-1

This article, along with others on similar topics, appears in the following collection(s):

All Immunology

http://nn.neurology.org//cgi/collection/all_immunology

EEG; see Epilepsy/Seizures

http://nn.neurology.org//cgi/collection/eeg_see_epilepsy-seizures

Epilepsy semiology

http://nn.neurology.org//cgi/collection/epilepsy_semiology

PET

http://nn.neurology.org//cgi/collection/pet

Information about reproducing this article in parts (figures,tables) or in its entirety can be found online at:

http://nn.neurology.org/misc/about.xhtml\#permissions

Information about ordering reprints can be found online:

http://nn.neurology.org/misc/addir.xhtml\#reprintsus

Neurol Neuroimmunol Neuroinflamm is an official journal of the American Academy of Neurology.

Published since April 2014, it is an open-access, online-only, continuous publication journal. Copyright

Copyright $\odot 2017$ The Author(s). Published by Wolters Kluwer Health, Inc. on behalf of the American Academy of Neurology. All rights reserved. Online ISSN: 2332-7812.

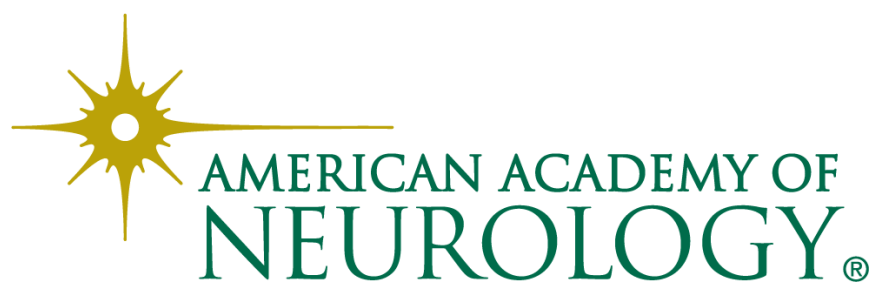

